\title{
The challenge of publishing research about a never-ending subject for marketing scholars: The country of origin
}

\section{Francesca Checchinato, Marta Disegna \& Tiziano Vescovi}

To cite this article: Francesca Checchinato, Marta Disegna \& Tiziano Vescovi (2018) The challenge of publishing research about a never-ending subject for marketing scholars: The country of origin, Journal of Global Scholars of Marketing Science, 28:2, 160-165

To link to this article: https://doi.org/10.1080/21639159.2018.1437356

曲 Published online: 14 Mar 2018.

Submit your article to this journal $₫$

Q View related articles $₫$

View Crossmark data ¿ 


\title{
The challenge of publishing research about a never-ending subject for marketing scholars: The country of origin
}

\author{
Francesca Checchinato $^{a}$ (D), Marta Disegna ${ }^{b}$ (D) and Tiziano Vescovi ${ }^{a}$

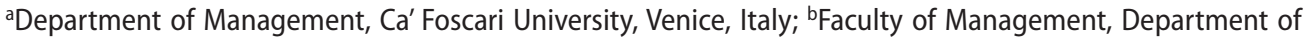 \\ Accounting, Finance \& Economics, Executive Business Centre, Bournemouth University, Bournemouth, UK
}

\begin{abstract}
The country of origin (COO) represents one of the main topics in the marketing literature and a large body of knowledge about it has already been published. This commentary essay tries to explain why it seems to be a never-ending subject for marketing scholars and the reason why the paper we published in this Journal few years ago contributed to the literature and has achieved the Google i-10 high citation-impact ranking. Analysing the effect of $\mathrm{COO}$ on a specific factor such as brand associations, the use of a methodology that cope with the critics of some scholars about the overstressed of $\mathrm{COO}$ in the past research, and the selection of an emerging market - the Chinese one - as country in which testing the $\mathrm{COO}$ have helped our paper to be cited. Based on these elements, some future research topics are also suggested.
\end{abstract}

\section{市场营销学界出版研究面临的挑战 : COO (原产地)}

原产地(COO) 是市场营销文献探讨的主题之一，大量相䏌知识材 料皆已出版发表, 但近年来, 这一主题热度可能将继续保持一种 积极上升趋势。

本文意在阐释为什么 COO (原产地) 看起来像是市场营销学 界永恒的话题。此外, 我们还将重点阐明几年前我们于本期刊上 发表的一篇论文丰富了市场营销文献, 并成功引起Google i-10的 高引用影响的原因。

䏌于 COO (原产地) 的研究如此活跃主要源于以下五方面因 素:1)研究结论仍未能一致;2)品牌受到COO不同方面的影响, 因 此, 学界还没有完成所有层面的分析;3)消费行为受到COO (原产 地）信息的影响，因此这一系列文献连同其有待分析许多理论和 不同方面也涉及到主题的展开4)爸于 $\mathrm{COO}$ (原产地) 的研究过去 主要聚焦于西方国家，因此需要对新兴国家(中国、巴西、印度)展 开新研究。5)在全球化的世界中,制造国往往不是品牌起源地, 许 多研究人员正试图评估这种差别是否以及如何影响产品的评估。

在我们的研究中(Checchinato, Disegna, \& Vescovi, 2013), 我们 试图阐释 $\mathrm{COO}$ 来填补前面提及的缺口: 1) 我们分析了 $\mathrm{COO}$ 对某个 特定因素的影响，比如品牌联想。2)我们利用方法论，来回应一些 学者全于在以往研究中过分强调 $\mathrm{COO}$ 诱因的批评3)选择一个新兴 市场——中国——作为试验COO的国家。

\section{ARTICLE HISTORY}

Received 30 March 2017

Revised 8 May 2017

Accepted 15 June 2017

\section{KEYWORDS}

Country of origin; China; brand associations; brand management; Italy

兊键词

原产地; 中国; 品牌联想; 品 牌管理; 意大利 
事实上, 我们研究考察了意大利产品的COO (原产地) 对中 国人自发品牌联想的影响，考察时我们避免了COO研究的一个主 要问题:消费者/调查对象没有被人为地接触 $\mathrm{COO}$ 。我们并不要求 评估研究人员所定义的与COO相䏌的品牌联想，而是要看到自发 的品牌联想。将知道COO的调查对象和不知道 $C O O$ 的调查对象分 别产生的自发联想进行对比，通过实例我们证明，COO并不是品 牌联想形成的真正诱因。

此外，本文在中国人口中对COO的影响进行评估旨在填补营销 文献的另一个空白，因为中国人口对意大利了解不足。

在人们意识中似乎存在着一种对 $\mathrm{COO}$ 的等级划分, 理想上就 是从宏观层面(多国地区, 如欧洲)开始, 再到微观层面(国家), 最 终到更微小的层面(区域, 省)。研究结果显示, 我们需要探讨对 于COO的认知是否会受到受研究的两个国家之间在文化、地理 经济和/或历史上所存在的差异的影响。

因此，即使本文分析诸如COO这样一个经典的话题，这些因素 的的本源也可以增加本篇文章的可引用性。

\section{The reasons why the country of origins is still an interesting subject}

In the marketing literature, the country of origin (COO) represents one of the most studied topics and the emphasis seems not decrease along the years. In fact, looking at the number of Google Scholar and Scopus indexed' papers mentioning COO in their title, it is still possible to observe a positive trend in recent years even if a large body of knowledge about this phenomenon has already been produced and published. This flourishing research activity mainly depends on the following five reasons: findings are not consistent and criticisms regarding the $\mathrm{COO}$ usefulness in marketing and communication strategies have emerged after years of study, fuelling the debate again; brands can be affected by different aspects that made up the COO and, as a result, scholars had not completed yet all the spectrum of analysis which would help marketers in managing brands in international context; consumer behaviour is affected by $\mathrm{COO}$ information, hence also this stream of literature with its many theories and aspects to be analysed is involved in the topic development in order to better understand behaviour patterns and psychological mechanisms; the economy of new emerging countries (such as China, India and Brazil) has become so important and different from the "old" economies that research about COO involving these new settings are needed; in the globalized world, the country of production is often different from brand origin and many researchers are trying to evaluate whether and how this discrepancy impacts on product evaluations (e.g. Johnson, Tian, \& Lee, 2016).

\section{Our position in the literature}

Published in 2013, our research (Checchinato, Disegna, \& Vescovi, 2013) examined the effect of the $\mathrm{COO}$ of Italian products on spontaneous brand associations in the Chinese population. A sample of Chinese students was asked to freely associate thoughts that come to their minds generated both reading the descriptions of six real branded products and looking at their pictures. In half of these descriptions, information about the Italian origin of the product was added, in the other half, instead, no information about the COO of the product was mentioned. Correspondence analysis and Chi-square test of independence suggested that Chinese consumers were not affected by the "made in Italy" when 
this information was added to products' description. Comparing spontaneous associations generated by respondents aware and unaware of the $\mathrm{COO}$, we demonstrated that $\mathrm{COO}$ was not a real cue in the brand association formation. In the debate about the influence of $\mathrm{COO}$, these results position our paper with scholars affirming that past research has inflated the influence of $\mathrm{COO}$ information because of the methodology used to test this impact (see for instance Samiee, Shimp, \& Sharma, 2005). In fact, in most of the published research the $\mathrm{COO}$ is artificially exposed and stressed, forcing consumers to not respond to the stimulus as they would do if it was a real buying situation. Since we agreed with this opinion, we tried to respond to the call of designing research where consumers are not forced to evaluate products based on the COO cue (Magnusson, Westjohn, \& Zdravkovic, 2011a). Our research did not stress the $\mathrm{COO}$ cue, but used it as one of the main features of the products, as it happens in a real-life shopping situation.

Our research contributed to the existing literature in two ways. Firstly, because it analysed how $\mathrm{COO}$ affects one specific and understudied variable, i.e. brand association, instead of over studied ones such as the generic "product evaluation", or more specific product quality, the purchase intention, or the willingness to pay. Secondly, because of its methodology, since we used a new way to measure whether and how spontaneous brand associations can change on the basis of the COO cue, trying to encompass the bias of some existing experiments mentioned in the literature (Magnusson, Westjohn, \& Zdravkovic, 2011b; Samiee, 2010; Samiee et al., 2005). As acknowledged by the literature, brand equity depends on brand association, defined by Aaker (1991) as any thoughts linked to the brand in the mind of the consumer, but measuring these thoughts is still difficult both for scholars and practitioners (Till, Baack, \& Waterman, 2011). Therefore, developing either new ways or new scales to measure this relationship represents a challenge in the marketing literature, also beyond the COO field. Our paper represents one of the first attempts in which brand associations' measures have been constructed, even if in a multiple categories setting as highlighted by Gordon, James, and Yoshida (2016), hence more research are needed. For example, new brand association scales, such as the one proposed by Gordon et al. (2016) for goods and services, as well as more comprehensive methodologies to capture the multiple facets of them (Supphallen, 2000), have to be considered and analysed. Research should be carried out trying to simulate both real-life and buying situations, without stressing the COO cue to avoid biased results.

\section{Research of the country of origin effects in an emerging country: The China case}

Moreover, since previous research highlighted that the COO effects depend on the countries involved in the study, the aim of evaluating the effects on the $\mathrm{COO}$ in the Chinese population was an attempt to fill a gap in the literature, because the majority of research are related to Western countries only. However, why researcher should think that emerging countries' consumers judge and consider the foreign origin of products in a different way? Two main reasons can be relevant: the consumer knowledge of the COO features; the ability of these consumers to evaluate branded products based on multiple cues.

Many consumers use COO stereotypes to evaluate products, but the knowledge of stereotypes linked to distant Countries is sometimes very weak, so adding this cue could mean nothing for certain populations. For instance, in our research we analysed Italian 
brands, but what does Italian origin mean for Chinese people? Are they able to add values to products thanks to this information? Some studies revealed that Italy has a strong image in some categories. Moreover, previous research also indicates that consumers in less developed economies prefer foreign brands coming from more developed countries or regions, because these brands are thought to represent high-quality and fashionable styles (see for instance Zhou \& Belk, 2004; Zhuang, Wang, Zhou, \& Zhou, 2008). Given these assumptions, in our research we expected to find at least these stereotypes attached to the "made in Italy" products presented to the sample, but this was not the case. One possible reason, that needs more investigations, is that our Chinese sample was not so aware of Italian stereotypes. Therefore, our findings revealed a need in studying whether the COO perception is affected by cultural, geographical, economic and/or historical distance between the two analysed countries. In fact, in our research we highlighted that some scholars recognize that the awareness of a $\mathrm{COO}$ would also differ according to the geographical distance. A hierarchy of COOs seems to exist in the people's mind and it ideally start from the macro level (multi-country areas), go through the micro level (countries) and finally to the nano level (regions, provinces). This fact has been successively remarked by Stoenescu, Capatina, and Cristea (2015, p. 2677) who stated "for a low COO affinity a positioning as 'Western European' rather than of a specific country could be more effective", as well as by Hu and Checchinato (2015), where the "Made in Italy" association was found not clear for most of the observed Chinese consumers who considered more comprehensible the idea of the "Made in Europe".

Concerning the consumers' ability in the evaluation of branded products based on multiple cues, it should be noted that consumers generally base their evaluations on various descriptive, inferential or informational cues and one of them is the COO. The ability of evaluating products also depends upon the consumer's education and their knowledge about the product category. In comparison with Western consumers, the Chinese ones have only recently begun to compare and judge brands, due to their institutional and political situations, and this can affect their evaluation process in different ways. Consistently with their culture, Chinese people give great importance to the functional elements of products as much as to the well-known brand. Brands are a signal of status, so their image and positioning gain greater importance because the cultural dimension of power distance and the relevance of the opinions of others (linked to collectivism in the Hofstede framework) are higher than in other countries. The importance of $\mathrm{COO}$ is therefore affected by the cultural context. As demonstrated in cross-cultural studies by Godey et al. (2012), in China the COO is less important than design, brand itself, price and guarantee.

\section{Future research suggestions}

Therefore, future research should consider the hierarchy level of the origins but also the population preferences in evaluating brands. New comparative studies which involve other developing or emerging countries are needed both to explore whether any cultural bias exists and to verify our findings beyond the Chinese market.

Moreover, the $\mathrm{COO}$ has been considered such a complex element that some scholars have preferred to divide it in Country of Design, Country of Brand, Country of Manufacturing and so on, to highlight the differences in the phenomenon. Concerning this vision and the scarce knowledge of developing countries' population about stereotypes of foreign countries, 
we embrace the notion of brand origin confusion (BOC) developed in the last decade literature. In fact, as highlighted by Magnusson et al. (2011a), it is almost impossible for consumers to keep track of design, part and assembly origins. Future research may analyse the $\mathrm{COO}$ effect on brand associations and the $\mathrm{BOC}$, comparing more countries both as the $\mathrm{COO}$ of the brand and as the country in which consumers evaluating these $\mathrm{COO}(\mathrm{s})$ live.

\section{Disclosure statement}

No potential conflict of interest was reported by the authors.

\section{ORCID}

Francesca Checchinato (D) http://orcid.org/0000-0002-0248-9001

Marta Disegna (iD http://orcid.org/0000-0002-3638-6772

Tiziano Vescovi (D) http://orcid.org/0000-0003-4152-5850

\section{References}

Aaker, D. A. (1991). Managing brand equity: Capitalizing on the value of a brand name. New York, NY: The Free Press.

Checchinato, F., Disegna, M., \& Vescovi, T. (2013). Does country of origin affect brand associations? The case of Italian brands in China. Journal of Global Scholars of Marketing Science, 23, 409-421. doi:10.1080/21639159.2013.818281

Godey, B., Pederzoli, D., Aiello, G., Donvito, R., Chan, P., Oh, H., ... Weitz, B. (2012). Brand and country-of-origin effect on consumers' decision to purchase luxury products. Journal of Business Research, 65(10), 1461-1470. doi:10.1016/j.jbusres.2011.10.012

Gordon, B. S., James, J. D., \& Yoshida, M. (2016). The development of brand association measures in multiple product categories: New findings and implications for goods and service brands. International Journal of Business Administration, 7(3), 140-152. doi:10.5430/ijba.v7n3p140

Hu, L., \& Checchinato, F. (2015). The country of brand communication in the retail setting: An analysis of Italian products in China. Australasian Marketing Journal (AMJ), 24(4), 325-332. doi:10.1016/j.ausmj.2015.10.005

Johnson, Z. S., Tian, Y., \& Lee, S. (2016). Country-of-origin fit: When does a discrepancy between brand origin and country of manufacture reduce consumers' product evaluations. Journal of Brand Management, 23(4), 403-418. doi:10.1057/bm.2016.13

Magnusson, P., Westjohn, S. A., \& Zdravkovic, S. (2011a). Further clarification on how perceived brand origin affects brand attitude: A reply to Samiee and Usunier. International Marketing Review, 28(5), 497-507. doi:10.1108/02651331111167615

Magnusson, P., Westjohn, S. A., \& Zdravkovic, S. (2011b). "What? I thought Samsung was Japanese": Accurate or not, perceived country of origin matters. International Marketing Review, 28(5), 454472. doi:10.1108/02651331111167589

Samiee, S. (2010). Advancing the country image construct - A commentary essay. Journal of Business Research, 63(4), 442-445. doi:10.1016/j.jbusres.2008.12.012

Samiee, S., Shimp, T. A., \& Sharma, S. (2005). Brand origin recognition accuracy: Its antecedents and consumers' cognitive limitations. Journal of International Business Studies, 36(4), 379-397. doi:10.1057/palgrave.jibs.8400145

Stoenescu, R.-D., Capatina, G., \& Cristea, A. (2015). The impact of counry-oforigin on brand positioning for luxury goods. In 15th EBES Conference - Lisbon (pp. 2665-2682). Cham: Springer.

Supphallen, M. (2000). Understanding core brand equity: Guidelines for in-depth elicitation of brand associations. International Journal of Market Research, 42(3), 319-361.

Till, B. D., Baack, D., \& Waterman, B. (2011). Strategic brand association maps: Developing brand insight. Journal of Product \& Brand Management, 20(2), 92-100. doi:10.1108/10610421111121080 
Zhou, N., \& Belk, R. W. (2004). Chinese consumer readings of global and local advertising appeals. Journal of Advertising, 33(3), 63-76. doi:10.1080/00913367.2004.10639169

Zhuang, G., Wang, X., Zhou, L., \& Zhou, N. (2008). Asymmetric effects of brand origin confusion: Evidence from the emerging market of China. International Marketing Review, 25(4), 441-457. doi:10.1108/02651330810887486 